\title{
SOME SAR STUDIES ON THE SENSE OF TASTE
}

\author{
by \\ LLOYD N. FERGUSON*, LORI LANG, GEORGE MORGA, HARRIETT PUGH, \\ CHARLOTTE VAN BUREN, CAREY WALKER, ROSE WILSON \\ and MANQUE WINTERS
}

California State University, Los Angeles, CA 90032 USA

Keywords: Trisubstituted benzenes, substituted nitroanilines, substituted nitrophenols, stimulus-receptor interactions, charge-transfer, hydrogen bonding, taste bud cells, conductivity, sodium ion transport

\begin{abstract}
Using the Shallenberger-Kier model as a molecular requirement for the sweet taste, adsorption and spectroscopic measurements on sweet and nonsweet analogs are described. Additional exploratory experiments were made in search of a set of parameters which could be used to predict the taste (sweet or nonsweet) of trisubstituted benzenes.
\end{abstract}

\section{INTRODUCTION}

Scientists of diverse disciplines are studying the sense of taste, essentially from three different perspectives. There are those, primarily organic chemists, who seek structure-taste relationships (SAR). A sub-group, "flavor chemists", analyze foods and examine the effects of flavor-enhancers, flavor-inhibitors, and flavor modifiers. A second category of interest is the mechanism of taste stimulation, being explored by biochemists, biophysicists and others. They are probing the mechanism of stimulus-receptor interaction, cell structure of the taste buds, and the triggering process of nerve transmission up to the brain. Thirdly, there are those interested in taste perception, especially psychologists. This includes the measurements of taste quality and intensity, taste preferences, and food flavors.

Recent work has shown that for a clearer elucidation of the mechanism of taste stimulation by sweet or bitter substances, studies must be made of (1) structure-activity relationships of the stimulus, '(2) the rate of development (reaction time), intensity, and longevity of response to the stimulus ("persistance"), (3) the nature of the stimulus-receptor interaction. (4) The influence of biosphere environment, i.e. ionic strength, viscosity, temperature, concentration of stimulus, etc., (5) biochemical factors affecting transduction of the nerve impulses to the brain, e.g. presence of critical enzymes, etc. As organic chemists, we have been particulary interested in the first and third factors above.

With respect to the sweet taste, a widely used working hypothesis has been that sweet molecules have a triangular region, $\mathrm{A}-\mathrm{H}, \mathrm{B}, \gamma$, in which $\mathrm{A}-\mathrm{H}$ is a proton-donor group, B a proton-acceptor function and $\gamma$ is a lipophilic moiety $(46,70)$.

\footnotetext{
* It was exactly 30 years ago that Dr. L.N. FERGUSON first became interested in the sweet nitroanilines while spending a sabbatical year in the Carlsberg Laboratorium under Professor HeINZ HoLTER.
} 


\section{STRUCTURE-ACTIVITY RELATIONSHIPS OF TRISUBSTITUTED BENZENES}

A variety of sweet trisubstituted benzenes conform to structure 1 .<smiles>[X]c1ccc([Z])c([X])c1</smiles>

1
$\mathrm{X}=\mathrm{NH}_{2}, \mathrm{OH},\left(\mathrm{CH}_{3}\right.$ in one case $)$

$\mathrm{Y}=$ o,p-directing groups, e.g., alkyl, alkoxyl, halogen, $\mathrm{NH}_{2}, \mathrm{OH}$

$\mathrm{Z}$ = electron-withdrawing groups, e.g., $\mathrm{NO}_{2}, \mathrm{CN}, \mathrm{CF}_{3}$, or lipophilic groups.

The sweet compounds 2 - 4 serve as examples.<smiles>COc1ccc([N+](=O)[O-])cc1O</smiles>

2<smiles>CCOc1ccc(C#N)cc1N</smiles>

3<smiles>Nc1cc(C(F)(F)F)ccc1F</smiles>

4

The dihydrochalcones 5 (42), phyllodulcins 6 (29), and flavanones $7(80)$, also have this orientation of substitution about the benzene ring ( $\mathrm{X}=\mathrm{OH}, \mathrm{Y}=\mathrm{OCH}_{3}$ )<smiles>COc1cc(O)c2c(c1)O[14CH2]C(=O)CC2</smiles>

5

(ca. 1500X)*<smiles>COc1ccc(C2Cc3cccc4c3C(=O)O[C@H]4O2)cc1O</smiles>

6 $(400 \mathrm{X})$

$\mathrm{G}=$ Rhamnosyl sugar, $\mathrm{HO}_{3} \mathrm{~S}-\left(\mathrm{CH}_{2}\right)_{3}-$, or $\mathrm{HO}_{2} \mathrm{C}-\mathrm{CH}_{2}-$<smiles>COc1ccc(C2CC(=O)c3c(O)cccc3O2)cc1O</smiles>

7<smiles>COc1ccc(Cc2ccccc2)cc1O</smiles>

8

$(350 X)$

Many reports have noted the effects on taste by changes made in $\mathrm{X}, \mathrm{Y}$, and $\mathrm{Z}$ of 1 . The most widely studied, of course, are the m-nitroanilines, reviewed by VERKADE (78). Some interesting comparisons are the following:

* Relative sweetness, Sucrose $=1 \mathrm{X}$ 
Changes in $\mathrm{X}$ or $\mathrm{Y}$<smiles>[X]c1ccc([N+](=O)[O-])cc1N</smiles>

9<smiles>[Y]c1ccc([N+](=O)[O-])cc1O</smiles>

$10(10)$<smiles>[Y]c1ccc(C(F)(F)F)cc1N</smiles>

11 (10)<smiles>COc1cc([N+](=O)[O-])ccc1N</smiles>

Sweet
Sweet: $\mathrm{Y}=\mathrm{OMe}, \mathrm{OEt}, \mathrm{O}-\mathrm{n}-\mathrm{Pr}, \mathrm{CH}_{3}, \mathrm{~F}, \mathrm{Cl}, \mathrm{Br}$, I (78).

Not sweet: $\mathrm{Y}=\mathrm{NH}_{2}(10)$.

Sweet: $\mathrm{Y}=\mathrm{OMe}, \mathrm{OEt}, \mathrm{CH}_{3}, \mathrm{Br}$

Not sweet: $Y=O-n-P r, O-i p r, O-n-B u$

Sweet: $\mathrm{Y}=\mathrm{F}, \mathrm{Cl}, \mathrm{Br}$<smiles>[Y]c1ccc(C2Cc3cccc4c3C(=O)OC4O2)cc1[X]</smiles>

$12(29,80)$<smiles>COc1ccc(B=Cc2ccccc2)cc1O</smiles>

$13(29,80)$
Y X
(a) $\mathrm{OMe} \quad \mathrm{OH}$ Sweet
(b) $\mathrm{OMe}$ OMe Bitter
(c) $\mathrm{OH}$
$\mathrm{OH}$ Tasteless
(d) $\mathrm{OH}$
H Tasteless

A - B

(a) $-\mathrm{CH}_{2}$ Tasteless

(b) $-\left(\mathrm{CH}_{2}\right)_{2}-\quad$ Sweet

(c) $-\left(\mathrm{CH}_{2}\right)_{3-}$ Tasteless

(d) $-\mathrm{CH}=\mathrm{CH}-$ Tasteless

(e) $-\mathrm{CH}-\mathrm{CH}_{2-}$ Bitter I $\mathrm{CH}_{3}$

(f) $-\mathrm{NH}-\mathrm{CH}_{2}$ - Sweet

(g) $-\mathrm{O}-\mathrm{CH}_{2} \quad$ Sweet

(h) $-\mathrm{S}_{-} \mathrm{CH}_{2} \quad$ Sweet

(i) $-\mathrm{CH}_{2}-\mathrm{NH}$ - Sweet

(j) $-\mathrm{CO}-\mathrm{CH}_{2}-$ Sweet

(k) $-\mathrm{CH}_{2}-\mathrm{O} \quad$ Tasteless

(l) -O-CO- Sweet

(m) -S-CO- Tasteless 
<smiles>[X]c1ccc(Cc2ccccc2)cc1[X]</smiles>

$14(80)$
Y
$\mathrm{X}$
(a) $\mathrm{OMe}$
$\mathrm{OH}$ Sweet
(b) $\mathrm{OH}$
OMe Tasteless
(c) $\mathrm{OEt}$
$\mathrm{OH}$ Sweet
(d) O-n-Pr
$\mathrm{OH}$ Tasteless
(e) $\mathrm{OMe}$
$\mathrm{NH}_{2}$ Tasteless<smiles>[X]c1ccc(C2CC(=O)c3c(O[CH])cccc3O2)cc1[X]</smiles>

$\begin{array}{llll} & \text { Y } & \text { X } & \\ \text { (a) } & \text { OMe } & \text { OH } & \text { Sweet } \\ \text { (b) } & \text { OHO } & \text { Me } & \text { Tasteless } \\ \text { (c) } & \text { OEt } & \text { OH } & \text { Sweet } \\ \text { (d) } & \text { O-n-Pr } & \text { OH } & \text { Sweet } \\ \text { (e) } & \text { OH } & \text { H } & \text { Tasteless }\end{array}$

$15(29,80)$

Changes in Z (49)<smiles>[Z]c1ccc(OC)c(O)c1</smiles>

16

$$
\begin{aligned}
\mathrm{Z} & =\mathrm{NO}_{2} & & \text { Sweet } \\
& =\mathrm{CHO} & & \text { Not sweet } \\
& =\mathrm{CO}_{2} \mathrm{Me} & & \text { Not sweet } \\
& =\mathrm{COOH} & & \text { Not sweet } \\
& =\mathrm{COHN}_{2}(78) & & \text { Not sweet }
\end{aligned}
$$<smiles>Oc1cc(C(F)(F)F)ccc1Cl</smiles>

It has been proposed that these analogs interact with a receptor site as diagrammed in 17 in which $\mathrm{X}$ and $\mathrm{Y}$ of 1 represent the ShallenberGer A-H,B moiety and the Z-phenyl portion is involved in hydrophobic bonding to the receptor (35).

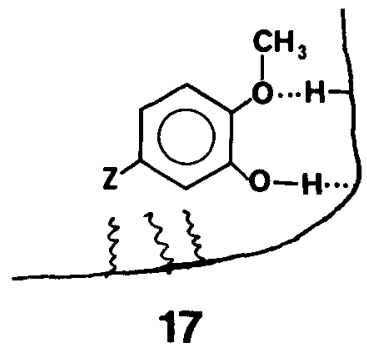

Receptor

Conformational requirements for $\mathrm{Z}$ among the flavanones and compounds related to phyllodulcin have been discussed by DicK and others (28). In a compound such as 5 quite possibly there are two A-H--B fragments and the $-\mathrm{CH}_{2}-\mathrm{CH}_{2}$-phenyl moiety forming the right hand ring is the hydrophobic region. In terms of this model, however, it is difficult to account for the sweetness of 18 to 20 unless one assumes the the $\mathrm{C}-\mathrm{H}$ bond para to $\mathrm{Z}$ is the $\mathrm{A}-\mathrm{H}$ moiety and the benzene ring is the $B$ site. 
<smiles>Cc1ccc(C#N)cc1N</smiles>

18<smiles>Cc1ccc([N+](=O)[O-])cc1C</smiles>

19<smiles>CCc1ccc([N+](=O)[O-])cc1O</smiles>

20

Sweet (78)

Sweet (35)

An A-H,B segment can easily be picked out in 21 and 22 which are sweet (37), but the $\mathrm{Z}$ fragment would be unusual.

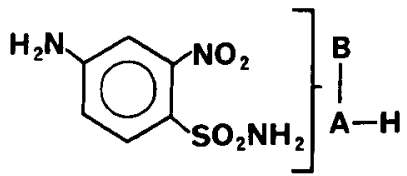

21<smiles>[H][Y](=O)C1CCCCCCC1[B]</smiles>

22

It has been suggested that the A-H,B fragment of the m-nitroanilines is at the nitro end of the phenyl ring $23(70)$.

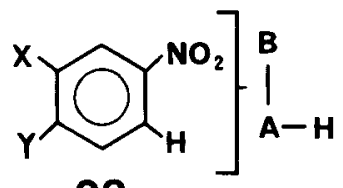

23

It is doubtful that the ortho $\mathrm{C}-\mathrm{H}$ bond would be polar enough to serve as the A-H bond (17). This is especially true for $\mathbf{2 4}$ which is weakly sweet (with a warming after-taste).<smiles>Cc1ccc(F)cc1N</smiles>

24<smiles>[X]c1ccc([N+](=O)[O-])cc1N</smiles>

25

Moreover, $\mathrm{nmr}$ spectra of a series of m-nitroanilines $\mathbf{2 5}$ indicate that the electron density and therefore, the polarity at the $\mathrm{C}_{4}$ or $\mathrm{C}_{6}$ positions do not parallel their relative sweetness (36). It is noteworthly at this point that the $\mathrm{nmr}$ spectra corroborate a deduction made from uv spectra (37) on the orientation of the $\mathrm{NO}_{2}$ group in the 4-substituted-5-nitroanilines 26.<smiles>[X]c1ccc(N)cc1[N+](=O)[O-]</smiles>

26

Both types of spectra indicate that the $\mathrm{NO}_{2}$ group is nonplanar with the the benzene ring. The absence of a strong band near $280 \mathrm{~nm}$ in the uv was taken as evidence of the nonplanar $\mathrm{NO}_{2}$ group. The chemical shifts of the $\mathrm{H}_{6}$ protons in the nonsweet 4-substituted nitroanilines are upfield 
of the $\mathrm{H}_{6}$ protons in the sweet 2-substituted isomers. This indicates that the $\mathrm{H}_{6}$ protons of the 4-substituted isomers 26 are in the shielding zone of a $\mathrm{NO}_{2}$ group facing those protons.

One might speculate that this lack of coplanarity of the $\mathrm{NO}_{2}$ and phenyl groups prevents a good fit of the Z-phenyl fragment for hydrophobic bonding, to account for their lack of sweet taste. To explore this notion, compounds 29 and 30 were synthesized (63). Since the NC-group is linear, there is no steric hindrance between it and the adjacent $\mathrm{CH}_{3}$ group of $\mathbf{3 0}$. As expected, 29 is not sweet but, somewhat surprisingly, 30 is not sweet either.

The foregoing comments make it clear that we need some experimental data which can be correlated with taste characteristics of substances. Early in our work we measured certain properties of the m-nitroanilines** which conceivably could be related to their tastes, such as surface tension of their solutions (51), basicities (52), association with water (51), and redox potentials (36). Quantitive<smiles>Cc1ccc([N+](=O)[O-])cc1N</smiles>

27

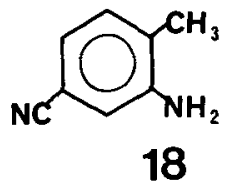

SWEET

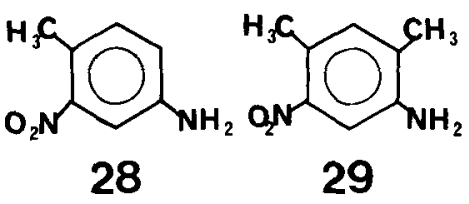

NOT SWEET

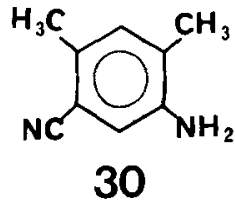

30

correlations can be drawn for some properties. Thus, DEUTCH and HANSCH used hydrophobic and HAMMETT substitutent constants (26), KIER used polarizabilities (46) and also molecular connectivity (46). IWAMURA used sterimol parameters (43) and we have used basicities or redox potentials plus HAMMETT constants of the substitutents to correlate sweetness of the $m$-nitro-anilines (48). Good correlation equations can be developed but always there are exceptions which implicate steric factors. For this reason, we turned to adsorption. H-bonding, inclusion complexation, and charge-transfer measurements.

It must be pointed out that it is possible there are different receptors for various classes of sweet compounds $(20,57,33)$, i.e. carbohydrates, cyclamates, benzene deriavatives, etc. However, all of our work has involved the simple trisubstituted benzenes for which it is not unreasonable to assume there is a single type of receptor.

\section{ADSORPTION MEASUREMENTS}

From the observation that the tasting process is quick, reversible, and involves low energies, it is assumed that the stimulus-receptor interaction does not involve covalent bond formation. A prevalent view is that it is a chemoreceptive process, i.e., a stereospecific interaction involving $\mathrm{H}$-bonds, and van der Waals and polarization forces. Two processes which are greatly affected by such stereospecific forces are adsorption and charge-transfer complexation, and therefore, we studied these two properties for sweet and nonsweet isomers under a wide variety of conditions.

RENQUIST (66) proposed that the taste sensation is initiated by the tastant being adsorbed onto the surface membrane of taste cells. Indirect evidence in support of this notion is found in the observation that the sweet proteins monellin and thaumatin have molecular weights over 11,000 and therefore probably elicit the taste response outside of the receptor cells. Also, activation energies for taste stimulation are of the order of magnitude found for adsorption processes (5), and taste responses $(15,4)$ follow adsorption isotherms. We found the adsorption of m-nitroanilines on hair, chosen as a proteinic surface, to fit quantitatively a Freundlich-type equation commonly used to correlate physical adsorption (51). Unfortunately, there was no consistent difference of adsorption behavior between sweet and nonsweet isomers.

** The nitroanilines are toxic and may be mutagenic or carcinogenic. Consequently our work has shifted to nitrophenols. 
A large number of thin layer chromatographic experiments have been conducted. It has been observed, among other things, that the sweet isomers are usually less strongly adsorbed than the nonsweet isomers on polar (talc) as well as on nonpolar (cyclodextrins) adsorbants, and that on $\beta$-cyclodextrin, the $\mathrm{D}$ - and L-isomers of tryptophane have about the same effect, but not always so when $\mathrm{Mn}^{+2}$ ion is added. Differences are also noted for $\mathrm{D}$ - and L-tryptophane with $\alpha$-cyclodextrin.<smiles>Nc1cc([N+](=O)[O-])ccc1O</smiles>

31

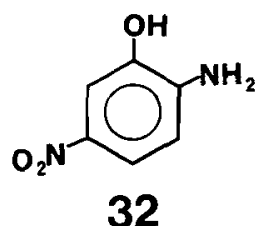

32

SWEET

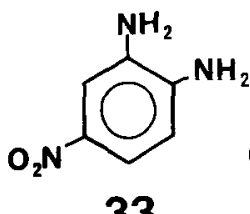

33

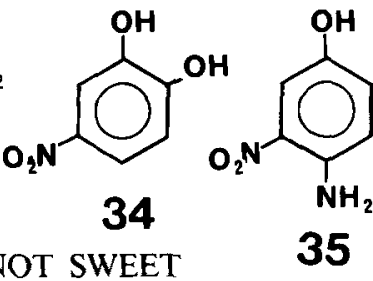

Some measurements were made on compounds $\mathbf{3 1}$ - $\mathbf{3 4}$ using filter paper presoaked in various solutions, Adsorbed substances were poly-d-lycine-HBr, D-, L-, or D, L-tryptophane, and the amino acids plus $\mathrm{K}^{+}$or $\mathrm{Mn}^{+2}$ ions, with a phosphate buffer solvent at $\mathrm{pH}=6,6.8$, and 7.2. In all cases, the relative $R_{f}$ values are $34 \simeq 31>32 \simeq 33$, i.e. the p-nitrophenols $>$ the p-nitranilines. Thus, there is no correlation with taste ( 31 and 32 sweet; 33 and 34 nonsweet). Another consistent difference is that the $R_{f}$ values with adsorbed L-tryptophane is almost always larger than with the $D$ isomer. The significance, if any, of this difference is not apparent at this time.

Additional exploratory TLC measurements were made using plates spread with $\beta$-cyclodextrin impregnated with $\mathrm{AgNO}_{3}, \mathrm{KCl}$, or $\mathrm{MgCl}_{2}$, with $\mathrm{D}$ - or L-tryptophane plus $\mathrm{Mg}^{+2}, \mathrm{Cu}^{+2}$, or $\mathrm{K}^{+}$ions. Water, phospate buffer, organic liquids, or salt solutions were used as developing solvents. Invariably there are differences between sweet and nonsweet m-nitro-anilines or -phenols, but there is no discernible pattern with sweetness. Attention was given to these selected metal cations because they could affect the conformation (through chelation) and the activity of the receptor site as has been observed for the influence of sodium ions on opiate receptors (72).

HPLC adsorption measurements were also made. By TLC on silica gel plates, it was found that a 9:1 benzene: acetic acid solution separated the sweet and nonsweet m-nitroanilines. Accordingly, this solvent was used for HPLC runs on a Porasil column. Sweet isomers have retention times (RT, in $\mathrm{cm}$ ) less than 2 and nonsweet isomers above 2.3. These results probably reflect relative basicities and, indeed, when $\mathrm{pK}_{\mathrm{a}}$ 's are plotted against $\mathrm{RT}$, two lines are obtained: one for the sweet isomers and one for the nonsweet analogs. Nevertheless, to follow this up, we made some HPLC studies on the four intriguing compunds 31 - 34. Using ethyl acetate as a solvent and with $\mu$-porasil columns, measurements were run under basic (10-20\% pyridine), neutral (pure solvent), and acidic (10-20\% glacial acetic acid) conditions. No particular pattern with respect to taste is noted, although the sweet analogs (31 and 32) come off of the column ahead of the nonsweet compounds with the $20 \%$ pyridine as well with the $20 \%$ acetic acid solvent. We then switched to a reverse phase carbohydrate column, using a phosphate buffer solvent at $\mathrm{pH}$ values of $6.0,6.8$, and 7.2. We also tried the $\mu$-bondapak C-18 column (very nonpolar) with the buffered solvent at the same pH's. The retention times show even less association with taste. These results are not encouraging for pursuing this approach in seeking a difference in adsorption characteristics between sweet compounds $(31,32)$ and their nonsweet analogs $(33,34)$.

If one assumes that all sweet molecules have the required shape and charge density to complement the receptor site for an interaction, then the adsorptive characteristics of sweet compounds as a group should differ from those of nonsweet compounds, provided one has the proper model adsorbent. One strategy to produce a model is to prepare specific silica gel adsorbents. For illustration, it has been shown by equilibration $(3,21,30)$ and by $\operatorname{TLC}(32,65)$, that silica gel may be precipitated in the presence of a template molecule and after the template has been removed by extraction, the silica exhibits greater adsorptive power for the template than for its isomers or similar compounds. 
It was hoped that when silica is precipitated in the presence of a sweet template, after removal of the template, the silica would selectively adsorb all sweet compounds in preference to nonsweet compounds.

It had already been reported that a quinine-templated gel adsorbs quinine in about 20 per cent greater amount than its stereoisomers quinidine and conchonidine (3). Since quinine is bitter, we first tested our notion to see if quinine-templated gel shows any selectivity toward other bitter compounds (34). Our gels showed selectivity toward quinine but not toward the bitter compounds naringen or phloraceptophenon-4-neohesperidoside. When a sweet $\mathrm{m}$-nitroaniline was used as a template, the templated gel showed a selectivity depending mostly upon the relative basicities of the adsorbed molecules. This was attributed to the acidic character of silica.

We extended this approach by using a neutral adsorbent such as a carbohydrate or polyamide. We polymerized acrylamide and acrylonitrile, separately, with benzoyl peroxide catalyst in methanol or dioxane solvent. The polymer was prepared in the presence or absence of a sweet, bitter, or tasteless template, the template removed by extraction, and the polymer powdered and spread on plates for TLC. The polyacrylamide gave glazed or brittle plates so that most measurements were made with the polyacrylonitrile polymer. Unfortunately, the templated polymers did not exhibit selective adsorption (aqueous buffer solvent) although in some runs, the data offered encouragement.

We made three modifications of this technique: (i) neutralize the template-silica gel plates with ammonia, (ii) polymerize acrylamide in aqueous solutions with persulfate catalyst as is done for the preparation of polymers for "gel electrophoresis" or proteins (16), (iii) use gels of the type used for "gel filtration" of proteins, e.g., Sephadex gels, which are crosslinked dextrans.

(i) Thin layer plates were prepared from silica gel produced without a template. Half of the plates were exposed to $\mathrm{NH}_{3}$ overnight. Sweet and nonsweet isomers were chromatographed using a buffer solvent. $\mathrm{R}_{\mathrm{f}}$ values changed on the $\mathrm{NH}_{3}$-treated plates but the per cent change reflected acidity of the substrates rather than their tastes. Attempts at partial neutralization by exposure to $\mathrm{NH}_{3}$ for short periods did not give reproducible results.

(ii) Acrylamide was polymerized with or without template molecules, using ammonium perchlorate catalyst in aqueous amine solutions as is normally done for gel electrophoresis. The polymer was usually a firm transparent gel which, when allowed to dry or when extracted with alcohol and dried, yielded a leathery solid. This was extremely difficult to grind. It swelled to globular gels when brought in contact with aqueous solutions. The feasibility of this technigue did not seem promising. Measurements will have to be made using the gel as formed, either with gravity elution or electrophoresis. Sephadex powders were swelled in aqueous (27) or methanol solutions and with or without template compounds. After the template was eluted, adsorptions of sweet and tasteless isomers were determined by measuring elution times. The data were very erratic and although reproducible data could be obtained for a given column, values varied for a given substance on different columns. It was finally concluded that any differences between reference and templated columns were not reliable.

A few attemps to use Sephadex powders for TLC were made. We had difficulty in standardizing conditions for reproducible $R_{f}$ values.

\section{CHARGE TRANSFER MEASUREMENTS}

Charge-transfer (C-T) complexation may play an important role in biological systems and has been shown to take place with several types of bio-molecules $(38,41,56,58,59,71,74,75,77)$. We conducted a variety of studies to explore the possibility of charge-transfer complexation being involved in the stimulus-receptor interaction. We first made spot tests (31), on the assumption that CT complexes would have a deep color. If, indeed, CT complexation were involved, we would expect a deeper color change for the sweet compounds than for the nonsweet analogs. This was not the case; color changes had no relation to the tastes. Spot tests and fusion techniques (50) 
show that the compounds form CT complexes at high concentration of the components. Quantitative measurements (colorimetric at several wavelengths in the visible, index of refraction, ir and Raman Frequency changes, and $\mathrm{nmr}$ sepctra) indicate that the CT formation constants are very small, i.e., $<0.5$. Colorimetric measurements at higher concentrations gave quantitative, reproducible adsorption changes but no clear pattern with taste. We used known polarizing, electron acceptors such as picric acid, iodine, 3-nitrophthalic acid, hexanitrosobenzene, 2,4,6-trinitrobenzoic acid, polyketo steroids, and caffeine. Since selectivity in complexation appears to improve when the two components have similar dimensions (68), we also used compounds which complement the m-nitroanilines, such as:<smiles>O=C(O)c1cc([N+](=O)[O-])ccc1[N+](=O)[O-]</smiles><smiles>O=C(O)c1ccc([N+](=O)[O-])c([N+](=O)[O-])c1</smiles><smiles>Nc1ccc([N+](=O)[O-])c([N+](=O)[O-])c1</smiles><smiles>N#Cc1ccccc1[N+](=O)[O-]</smiles>

To explore the possibility of key metal ions being involved, we made spot tests on mixtures of sweet and nonsweet analogs with $\mathrm{Mg}^{+2}, \mathrm{Ni}^{+2}, \mathrm{Cu}^{+2}, \mathrm{Zn}^{+2}, \mathrm{~K}^{+}$, or $\mathrm{Mn}^{+2}$ ions, and when the sweet or nonsweet (D- and $\mathrm{L}-$ ) isomers of asparagine were added.

In none of these experiments was there a pattern to link CT complexation to the stimulus-receptor interaction for a sweet taste.

\section{HYDROGEN BONDING STUDIES}

SHALLENBERGER (69), and LindLEY (54) have shown that among some isomeric sugars, the sweeter isomer exhibits a sharp ir band above $3400 \mathrm{~cm}^{-1}$ (free $\mathrm{OH}$ ), which is not present in the spectra of the nonsweet or only slightly sweet isomers. The implication is that the isomer with a "free" $\mathrm{OH}$ group can form an intermolecular $\mathrm{H}$-bond with the receptor site but the potential $\mathrm{A}-\mathrm{H}$ of the nonsweet analogs is tied up by internal $\mathrm{H}$-bonding.

In an attempt, to mimic partially the reciprocal $\mathrm{H}$-bonding implied in the A-H,B working hypothesis, we measured ir spectra of certain sweet and tasteless analogs in two environments. System $I$ is one which can serve as a proton-donor and -acceptor in H-bonding, whereas System II can serve only as a proton-acceptor.

System I solvents :<smiles>CCOCCO</smiles><smiles>COCCO</smiles><smiles>COCCCO</smiles><smiles>CNC(C)=O</smiles>

System II solvents:

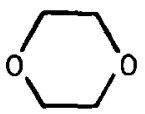

We are mindful of the somewhat similar situation for inhalational anesthetics. It has long been known that there is an association between hydrophobic character and anesthetic potency. Recently, through ir measurements, it was shown that H-bonding can produce perturbations of molecular attractions, and plays an important role in the mechanism of anesthesia (67).

The spectra of 19 and $31-34$ were measured in the $3000-3700-\mathrm{cm}^{-1}$ range in the inert solvent nitrobenzene, to exhibit bands as follows: 
<smiles>Cc1ccc([N+](=O)[O-])cc1C</smiles>

19<smiles>Nc1cc([N+](=O)[O-])ccc1O</smiles>

31<smiles>Nc1ccc([N+](=O)[O-])cc1O</smiles>

32

(sweet)

$3400 \mathrm{~cm}^{-1}$ 3500

$3630(w k)$<smiles>Nc1ccc([N+](=O)[O-])cc1N</smiles>

33

(nonsweet)

$3500 \mathrm{~cm}^{-1}(\mathrm{~s})$

3650 (v wk)<smiles>O=[N+]([O-])c1ccc(O)c(O)c1</smiles>

34

(nonsweet)

$3400 \mathrm{~cm}^{-1}(\mathrm{~s})$

3450

A complexing reagent methylformamide (MF), dimethylformamide (DMF), or 3-methoxypropanol (3MP) was added in equal amounts to the reference and sample cells. All three mixtures have a broad band near $3050-3200 \mathrm{~cm}^{-1}$ but produce no other changes in the spectra of the sweet analogs. With 33, a broad band appears stronger than the $3500 \mathrm{~cm}^{-1}$ band. The two bands of 34 become one envelope.

The spectra of 31 - 34 - were measured in the $3000-3700 \mathrm{~cm}^{-1}$ range in dioxane:

31

$3230 \mathrm{~cm}^{-1}$

3370

3470

3590

\section{2}

$3250 \mathrm{~cm}^{-1}$

3370

3460
33

$3280 \mathrm{~cm}^{-1}$

3380

3450
34

$3250 \mathrm{~cm}^{-1}$

3400 (sh)

3500

3600

When 3-methoxyethanol is added to both cells, two bands of 31, 32, and 33 are diminished and one band is enhanced. More experiments need to be done here. In any case, the significance of these spectral changes in nitrobenzene and dioxane is not clear at this time.

We also examined (8) the ir spectra of 36 and 37 in System I and II solvents.

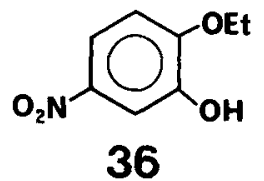

Sweet<smiles>CC(C)Oc1ccc([N+](=O)[O-])cc1O</smiles>

Nonsweet

The spectra of both compounds are almost identical in dioxane but the broad band in the 3200-3600 $\mathrm{cm}^{-1}$ region differs somewhat for the two analogs when measured in System I solvents. The band for the ethoxy derivative (36) has a break in the envelop near $3400-3500 \mathrm{~cm}^{-1}$, which indicates the presence of a stronger free $\mathrm{OH}$ peak. We are exploring this small difference in spectra to see if it is a general difference between sweet and nonsweet compounds or merely an artifact.

We are aware that $\mathrm{H}$-bonding alone will hardly distinguish sweet from nonsweet stimuli. Although the H-A,B fragment is necessary for a sweet taste (according to our working hypothesis), it does not assure a sweet taste. There must be a hydrophobic segment nearby which determines the intensity of sweetness. However, the hydrophobic portion of compounds $\mathbf{3 1}-\mathbf{3 4}$ is identical (we believe the nitrophenyl group is the hydrophobic segment, not the H-A,B fragment). In any event, the only differences are the $\mathrm{NH}_{2}$ - and $\mathrm{OH}$ - substituted ends so the sweet taste of 31 and 32 must be controlled in this area of the molecules by having the required conformation and $\mathrm{H}$-bonding character of the $\mathrm{NH}_{2}$ and $\mathrm{OH}$ groups. 


\section{STIMULUS-RECEPTOR INTERACTIONS}

Direct studies are being made of the stimulus-receptor interaction in taste perception. Although a taste receptor molecule has not been convincingly isolated, a number of taste receptor extracts has been prepared for exploring this chemoreceptive step. For example, studies have been made using homogenates of bovine taste papillae (76), cell suspensions from papillae rich in cells morphologically similar to taste bud cells (11), monolayers of lipids from bovine tongue epithelium (1), catfish taste epithelium fractions $(12,47)$, and from other preparations from bovine and human tongues $(14,62)$.

Most studies have taken the view that the taste receptors are proteinic in nature. For illustration, a determination was made of the amino acid composition of the total proteins precipitated from the surface tissue of the tip of a human tongue (2). Unlike bulk beef tongue, these proteins contain no cystine. Tongue-surface proteins differ from the polypeptide collagen, in that the former have tryptophane, less proline and glycine, and a higher percentage of lycine. The energies of complexation of several sugars with various amino acids in solution correlate well with relative sweetness of the sugars (53).

Taste sensitive proteins from tongue tissue (sweet-sensitive from cows $(23,61)$ and bitter-sensitive from pigs $(22,60)$ ) have been isolated which exhibit selective interaction with sweet or bitter substances, respectively.

We made similar measurements on horse tongue tissue, since horses like sugar (9).

The upper, rear-third surface tissue was homogenized in a Waring blender with a $0.1 \mathrm{M}$-phosphate buffer, $\mathrm{pH} 6.8$, at $0.5^{\circ}$. The homogenate was squeezed through cheese cloth, the liquid centrifuged at $4400 \mathrm{rpm}$ for $40 \mathrm{~min}$. at $10^{\circ}$. The supernatant was divided into fractions soluble in 10,20 , $40 \%$ ammonium sulfate. Solutions were prepared containing, for example,

$\mathrm{P}=1 \mathrm{ml}$ protein solution $+1 \mathrm{ml} \mathrm{H}_{2} \mathrm{O}$

$\mathrm{S}=1 \mathrm{ml}$ tastant solution $+1 \mathrm{ml} \mathrm{H}_{2} \mathrm{O}$

$\mathrm{M}=1 \mathrm{ml}$ tastant solution $+1 \mathrm{ml}$ protein solution.

Then values were determined for $\mathbf{M}-(\mathbf{P}+\mathbf{S})$ from spectrophotometric or index of refraction measurements on $\mathrm{M}, \mathrm{P}$, and $\mathrm{S}$.

Deviations from additivity are taken as a measure of interaction. From these data, it was deduced that the $40 \%-\left(\mathrm{NH}_{4}\right)_{2} \mathrm{SO}_{4}$ fraction does interact with sucrose but not with the sweet m-nitroanilines or with neohesperidine dihydrochalcone (sweet).

This technique has been adversely criticised by showing that such deviations from additivity are not unique to taste bud papilla and that the effect is not specific for sweet compounds (14).

A more reliable indication of stimulus-receptor interaction is the binding that occurs between isotopically labelled stimuli and preparations derived from taste papillae or taste bud cells. Thus, CAGAN has shown that ${ }^{14} \mathrm{C}$-labelled sucrose, but not tasteless lactose, binds preferably to taste tissue over nontaste tissue of the bovine tongue $(60)$. It has been reported that bovines strongly prefer sugars in two-choice preference tests (44), and it has been shown that sugars preferred by cows do bind to a greater extent to tissue membranes and homogenates containing taste receptors than to preparations from lingual tissue that is devoid of taste buds $(55,60)$. It has also been shown by polyacrylamide gel electrophoresis or Sephadex gel filtration that sweet sensitive proteins can be extracted from bovine tissue which bind with ${ }^{14} \mathrm{C}$-labelled fructose (40).

More significantly, CAGAN and coworkers have shown that the channel catfish contains taste receptors sensitive to amino acids located on its body surface and barbels. The plasma membranes adsorb certain amino acids and the degree of binding of these isotope-labeled amino acids parallels certain behavioral and electrophysiological responses and biochemical activities (13).

\section{MISCELLANEOUS SAR STUDIES}

In search of a multicomponent parameter that could be used to predict whether or not a compound is sweet or even bitter, a parameter that is semi-quantitatively related to sweetness, we have looked 
at a variety of properties of sweet and tasteless analogs (36). For example, we reported some years ago on the surface tension and redox potentials (51), uv spectra (37), and basicity (52) of the m-nitroanilines. Some additional properties examined will be described here.

\subsection{Conductivity measurements}

It is conceivable that saliva plays a role in the taste mechanism. For instance, it was reported that only when the tongue of a taster is moistened with saliva can that person taste PTC, whereas the dry tongue cannot, nor can it taste PTC when the saliva of a "nontaster" is used (18). Also, it has been observed that surface active agents affect the relative taste intensities of sweetness and of other taste qualities (24). Since ions do produce taste sensations, e.g. salts may be bitter, salty, or sweet, and acids are sour, we wondered if sweet and nonsweet compounds exert different effects on some ion in our saliva. As a probe of this notion, we measured the electrical conductivity of aqueous solutions of a variety of compounds alone and in the presence of saliva. We obtained the following results:

(1) The conductances (typical Wheatstone Bridge circuit) of $10^{-3} \mathrm{M} \mathrm{m}$-nitroaniline solutions were measured at $37.5^{\circ}$ alone and when $1 \mathrm{pt}$ of filtered saliva to $10 \mathrm{pts}$ of the solutions were mixed. In each case, the increase in conductance by the addition of saliva was greater for the sweet isomer and the increase was roughly proportional to the sweetness of the m-nitroaniline (7).

(2) The above experiments were repeated, including sucaryl and sucrose, and again the addition of saliva increased the conductance of sweet solutions more than those of nonsweet substances (73).

(3) Again, the experiments were repeated, this time using conductivity water and making measurements at room temperature (ca $\left.25^{\circ}\right)(48)$. This time there were no significant differences in conductivity increment for sweet and nonsweet analogs upon the addition of saliva. D- and L-tryptophane were included in this study.

It was further observed that there was no significant difference between the effects of sweet and nonsweet compounds on the conductance of $\mathrm{KCl}$ or $\mathrm{NaCl}$ solutions. It was noted that the saliva of a "nontaster" was 50 per cent higher than that of a "taster" but still no difference in effects from sweet and nonsweet compounds.

(4) Once more, conductivity measurements were made, this time in tap water and in low-quality conductivity water, and varying the amount of saliva added (79). Measurements were made on the sweet and nonsweet 2- and 4-methoxy-5-nitroaniline and compounds 31 - 34.

Again, there were no consistent differences in conductivity changes between sweet and nonsweet compounds.

In spite of the encouraging initial results of projects (1) and (2), this approach offers little promise.

\subsection{Sodium ion transport through tissue membrane}

Irrespective of the nature of the stimulus-receptor interaction, it is quite possible that the nerve impulse leading to a taste perception is triggered by a change in flux of sodium or potassium ions across the receptor membrane. To explore this notion, we measured the transport of sodium ions across a cell membrane in the presence of sweet or nonsweet m-nitroanilines. We chose the abdominal skin from single-pithed frogs for several reasons: Frog skins can easily be separated into sheets and they have a high specificity for differentiating $\mathrm{Na}^{+}, \mathrm{K}^{+}$, and $\mathrm{Rb}^{+}$ions. These properties are found somewhat in taste cells $(6,39)$. The procedure for measuring sodium ion transport, using radioactively labelled $\mathrm{Na}^{+}$, was similar to that described in the literature (64). Cognizance was taken of the fact that the rate of sodium ion transport through frog skin is affected by the oxygen partial pressure and the age of the frog, as well as other factors.

From our experiments, it was concluded that sweet and nonsweet m-nitroanilines, with or without 
added saliva, have no influence on the rate of transport of sodium ions across frog skin. Attention is called here to some related reports. For example, sodium ion deprivation alters neural responses to gustatory stimuli (19). Moreover, an in vitro preparation of the dorsal epithelium of the dog tongue actively transports ions, and recent results suggest that there is a current composed of inward sodium ion movement and outward chloride ion movement (25). In the case of olfaction, electrophysiological measurements on frog olfactory receptor sheets indicate that upon exposure to odorants, at least part of the current is due to increased permeability of the receptor cells to sodium ions (62).

\section{PRESENT OUTLOOK}

Based on the work of others, and that in our laboratories, we believe that the SHALLENBERGER-KIER tripartite model is a good working hypothesis for SAR studies of sweetness. We are still hopeful of finding a compound that will mimic in vitro the stimulus-taste receptor interaction, or at least one that gives data which when combined with certain adsorption measurements, will distinguish sweet from nonsweet compounds. We are looking for a probe compound which will reciprocally form two $\mathrm{H}$-bonds with the stimulus and exert hydrophobic bonding at its tail with the Z-phenyl portion of compound $\mathbf{1}$.

\section{ACKNOWLEDGEMENT}

This work was supported by the Minority Biomedical Research Program of the National Institutes of Health, grant number RR-08101.

\section{REFERENCES}

1. Aiuchi, T., N. Kamo, K. Kurihara \& Y. KobaTAKE: Physicochemical studies of taste reception VI: Interpretation of anion influences on taste reponse. Chem. Senses and Flavor 2, 107 (1976)

2. BARnes, C.J. \& L.N. Ferguson: Amino acid composition of proteins from surface tissue of the tongue. Nature 186, 617-619 (1960)

3. BeCketT, A.H. \& P. ANDERSON: The determination of the relative configuration of morphine, levorphanol, and L-phenazacine by stereoselective adsorbents. Nature 179, 1074 (1957). J. Pharmacy and Pharmacology suppl. 12, 228T (1960)

4. Beidier, L.M.: Flavor research and food acceptance. Reinhold Publishing Corp., N. Y., New York, 3-28 (1958)

5. BEIDLER, L.M.: Olfaction and taste. Ed. Y Zotterman, Macmillan Co., N. Y., New York, 133 (1963)

6. BEST, C.H. \& N.B. TAYLOR: The living body. 4th ed., Holt, Rienhart, and Winston, N. Y., New York (1961)

7. BOYD, R.E.: Unpublished work under an NSF Summer Institute Program at Howard University (1961)

8. BRAGANZA, R.: Unpublished work supported in part by NSF-URP grant at California State University, Los Angeles (1981)
9. BRAGG, R.W.: unpublished results supported by the Minority Biomedical Research Program of the Division of Research Resources NIH grant RR 08101-3 (1975)

10. BragG, R.W., Y. Chow, L. Dennis, L.N. Ferguson, S. Howell, G. Morga, C. Ogina, H. Pugh \& M. WINTERS: Sweet organic chemistry. J. Chem. Ed. 55, 281-285 (1978)

11. Brand, J.G. \& R.W. CaGan: Biochemical studies of taste sensation III. Preparation of a suspension of bovine taste bud cells and their labeling with a fluorescent probe. J. Neurobiol. 7, 205-220 (1976)

12. Cagan, R.H.: Biochemical studies of taste sensation. VII. Enhancement of taste binding to catfish taste receptor preparation by prior exposure to the stimulus. J. Neuróbiol. 10, 207-220 (1979)

13. Cagan, R.H.: Recognition of taste stimuli at the initial binding interaction, in Biochemistry of Taste and Olfaction, edit. by R.H. Cagan and M.R. Kare, Academic Press, New York, 175-203 (1981)

14. CAGAN, R.H. \& R.W. MORRIS: Biochemical studies of taste sensation. VI. Binding to taste tissue of $\left({ }^{3} \mathrm{H}\right)$-labeled Monellin, a sweet-tasting protein. Proc. Natl. Acad. Sci. USA 76, 1692 (1979)

15. Cameron, A.T.: The taste sense and the relative 
sweetness of sugars and other sweet substances. Sugar Research Foundation Scientific Rpt. ser 9 (1947)

16. Chrambach, A. \& D. Rodbard: Polyacrylamide gel electrophoresis. Science 172, 440-451 (1971)

17. Ciajolo, M.R., F. Lel, T. Tancredi, P.A. Temussi \& A. TUZI: Interaction of conformationally flexible agonists with the active site of sweet taste. A study of arylureas. J. Med. Chem. 26, 1060-1065 (1983)

18. COHEN,J.\&D.P. OGDEN: Taste blindness to phenyl thiocarbamide as a function of saliva. Science 110 , 532-533 (1949)

19. Contreras, R.J. \& M. Frank: Sodium deprivation alters neural responses to gustatory stimuli. J. Gen. Physiology 73, 569-594 (1979)

20. Crosby, G.A., G.E. Dubots \& R.E. Wingard: The design of synthesic sweeteners. Drug Design, Vol. VIII, ed. E.J. Ariens, Academic Press, N. Y., New York, chap. 5 (1979)

21. CURTI, R. \& U. Colombo: Chromatography of stereoisomers with "tailor made" compounds. J. Amer. Chem. Soc. 74, 3961 (1952)

22. Dastoli, F.R., D.V. Lapiekes \& A.R. Doig: On comparison of interactions of a bitter-sensitive protein from procine tongues with human taste thresholds. Nature 218, 884 (1968); F.R. Dastoli, Nature 223, 524-525 (1969)

23. DASTOLI, F.R \& S. PricE: Sweet-sensitive proteins from bovine taste buds: Isolation and assay. Science 154, 905 (1966)

24. DeSimone, J.A. \& G.L. Heck: Surface active taste modifiers: A comparison of the physical and psychophysical properties of gymnemic acid and sodium lauryl sulfate. Chemical Senses 5, 317-330 (1980)

25. DeSimone, J.A., G.L. HeCK \& S.K. DeSimone: Active ion transport in dog tongue: A possible role in taste. Science 214, 1039-1041 (1981)

26. DeutsCh, L.W. \& C. HansCh: Dependence of relative sweetness in hydrophobic bonding. Nature 211,75 (1966)

27. Dewhurst, F.: Student experiments on the gel filtration of proteins. J. Chem. Educ. 46, 864 (1969)

28. Dick, W.E., JR.: Structure-taste correlations for flavens and flavanones conformationally equivalent to phyllodulcin. J. Agric. Food Chem. 29, 305-312 (1981)

29. Dick, W.E., JR. \& J.E. HodGE: A sweet analog. J. Agric. Food Chem. 26, 723 (1978)

30. DickeY, F.H.: Specific adsorption. J. Phys. Chem. 59, 695 (1955)

31. Epstein, S.S., I. Bulon, J. Koplan, M. Small \& N. MANTEL: Charge-transfer complex formation, carcinogenicity, and photodynamic activity in polycyclic compounds. Nature 204, 750 (1964)

32. ERLENMEYer, H. \& H. Bartels: Uber das problem der Ähnlichkeit in der chemie Dünnschichtchromatographic mit spezifisch adsorbierenden silikagelen I. Helv. Chem. Acta. 47, 46-51 (1964)

33. Faurion, A., S. Saito \& P. MacLeod: Sweet taste involves several distinct receptor mechanisms. Chemical Senses 5, 107-121 (1980)

34. FERGUSON, L.N.\& R.M. Horowitz: unpublished work in the Fruit and Vegetable Chemistry Laboratory, U.S. Department of Agriculture, Pasadena, CA (1967)

35. Ferguson, L.N.: Bio-organic mechanisms II: Chemoreception. J. Chem. Ed. 58, 456-461 (1981)

36. Ferguson, L.N., R.W. BragG, Y. Chow, S. HoWELL \& M. WINTERS: Flavor of food and beverages., eds. G. Charalambous \& G. Inglett: Biomolecular studies of a class of sweet compounds. Academic Press, N. Y., New York, 91-96 (1979)

37. FERGuson, L.N. \& L.G. CHILDERS: U.V. spectroscopic studies of some sweet and nonsweet isomeric m-nitroanilines. J. Organic Chem. 25, 1971 1975 (1960)

38. Gray, A.P.: Cancer causes/cures. Chem and Eng. News, p. 5 (Nov. 17, 1975)

39. HENDRICKS, S.B.: Salt transport across cell membranes. Amer. Sci. 52, 306 (1964)

40. HiJI, Y. \& M. SATo: Taste sensitive proteins. Nature New Biol. 244, $91-93$ (1973)

41. Hollstein, U.: Aclinomycin. Chemistry and mechanism of action. Chem. Revs. 74, 625-652 (1974)

42. Horowitz, R.M. \& B. Gentile: Citrus-based Dihydrochalone sweeteners: in Sweeteners and Dental Caries. Eds. J.H. Shaw \& G.G. Roussos, Informational Retrieval, Inc., Washington, D.C., 291-299 (1978)

43. IwAMURA, H.: Structure-taste relationships of perillartine and nitro- and cyanoaniline derivatives. J. Med. Chem. 23, 308-312 (1980)

44. KARE. M.R. \& M.S. FICKEN: Dukes physiology of domestic animals. Ed. M.J. Swenson 8th Ed; Cornell University Press; Ithaca, New York, 285 (1963)

45. KIER, L.B: A molecular theory of sweet taste. J. Pharm. Sciences 61, 1394-1397 (1972)

46. KIER, L.B. \& L.H. HALL: Molecular connectivity in Chemistry and Drug Research. Academic Press, N. Y., New York (1976)

47. KRUEGER, J.M. \& R.H. CAGAN: Biochemical studies of taste sensation. IV. Binding of $\mathrm{L}-\left({ }^{3} \mathrm{H}\right)$ alanine to a sedimentable fraction from catfish. J. Biol. Chem. 251, 88 (1976)

48. LANG, K.J.: Some conductivity and ion transport 
studies on the sense of taste. M.S. thesis, Howard University (1966)

49. LANG, L. \& L.N. Ferguson: SAR studies on the sense of taste. Presented at the 9th Annual Minority Biomedical Support Symposium. April4, 1981, Albuquergue, N.M. Re. the COOH group, see also Trinti, J.M., D. Durozard, C. Nofre, Naturwissen 67, 193 (1980)

50. Laskowski, D.E., D.G. Grabar \& W.C. MCCRONE: 2,4,7-Trinitrofluorenone as a reagent for microscopic fusion analysis. Anal. Chem. 25, 1400 (1953)

51. LAWRENCE, A.R. \& L.N. Ferguson: Exploratory physicochemical studies on the sense of taste. Nature 183, 1469-1471 (1959)

52. LAWRENCE, A.R. \& L.N. FeRguSON: Dissociation constants of some sweet and tasteless isomeric m-nitroanilines. J. Org. Chem. 25, 1220-1224 (1960)

53. LeE, C.K., S.E. MatTaI \& G.G. BiRCh: Structural functions of taste in the sugar series. Sugar-amino acid interaction as an index of sugar sweetness. J. Food Sci. 40, 390 (1975)

54. LiNDLEY, M.G., G.G. BiRCH \& R. KHAN: Sweetness of sucrose and xylitol. Structural considerations. J. Sci. Food Agric. 27, 140-144 (1976)

55. Lum, C.K.L. \& R.I. Henkin: Sugar Binding to purified fractions from bovine taste buds and epithelial tissue. Relationships to bioactivity. Biochem. Biophys. Acta. 421, 380 (1976)

56. MACHMER, P. \& J. DucheSNe: Charge-transfer between nucleic acid bases and chloranil. Nature 206, 618 (1965)

57. MCGLINCHEv, G.: Structure-activity studies of sulfamate sweeteners II: Semiquantitative SAR for sulfamate $\left(\mathrm{RNHSO}_{3}\right)$ sweeteners. The role of R. J. Pharm. Sci. 70, 933-935 (1981)

58. NAGChaudhuRE, J. \& R. SURI: Donor-acceptor interactions in biomolecules: Pt I - certain enzymecoenzyme models. Indian J. Chem. 13, 1032 (1975)

59. Plath J.R.: Carotene-donor-acceptor complexes in photosynthesis. Science 129, 372 (1959)

60. PrICE, S.: Putative bitter-taste receptor from porcine tongues. Nature 221, 779 (1969)

61. PrICE, S.: Chemoreceptor proteins from taste buds. Agric and Food Chem. 17, 709-711 (1969)

62. PRICE, S.: see Chemoreception Research in the USSR. Chemical Senses 6, 63 (1981)

63. PUGH, H.: unpublished work supported by NIH under its Minority Biomedical Research Program, Grant RR 08101 (1975)

64. QuinNeY, P.R. \& H.A. SwARTZ: Active transport of sodium ions across frog skin. J. Chem. Educ. 41, 159-160 (1964)

65. REED, G.H. \& L.B. RoGERS: Adsorption of methyl orange and ethyl orange on tailored silica gels. Anal. Chem. 37, 861-863 (1965)

66. RENQUIST, Y.:Über den Geschmack. Scand. Arch. Physiol. 38, 97-201 (1919)

67. SANDORFY, C.: Intermolecular interactions and anesthesia. Anesthesiology 48, 357 (1978); s.a., Hobza, P.F. Mulder \& C. Sandorfy, J. Amer. Chem. Soc. 104, 925 (1982)

68. Schenk, G.H., P.W. Vance, J. Pietrandea \& C. MoJzIs: Study of the Pi complexes of 2,4,7-Tri-nitrofluorenone with phenols, aromatic hydrocarbons, and aromatic amines. Anal. Chem. 37, 372 (1965)

69. Shallenberger, R.S.: Hydrogen bonding and the varying sweetness of sugars. J. Food Science 28, 584 (1963)

70. Shallengerger, R.S. \& T.E. ACREE: Molecular theory of sweet taste. Nature 216, 480-482 (1967). S.a.W.G. Guild, Jr. J. Chem. Educ. 49, 171 (1972)

71. SLIFKIN, M.A.: Charge-transfer interactions of biomolecules. Academic Press, N. Y., New York (1971)

72. SNYDER, S.H.: Opiate receptors and internal opiates. Scientific American 236 (1), 44-56 (March 1977)

73. SWABY, M.: unpublished work, undergraduate research, Howard University (1963)

74. SZENT-GYORGY, A.: The living state and cancer. M. Dekker, N. Y., New York (1978)

75. TAYLOR, L.A. \& H.K. MAO: Crystal structure of serotonin picrate, a donor-acceptor complex. Science 170,852 (1970)

76. VAN DER WEL, H.: Physiological action and structure characteristics of the sweet-tasting proteins. Trends in Biomedical Sciences 122, (May 1980)

77. Vasundhara, T.S. \& D.B. Parihar: Studies of pyrazines as their $n-\pi$ charge-transfer complexes with some nitro aromatic compunds. J. Chromatogr. 194, 254 (1980)

78. VERKADE, P.E.: On organic compounds with a sweet and/or a bitter taste. II Farmaco-Ed. Sci. (Eng) 23, 248 (1968)

79. WALKER, C.E.: Undergraduate research project. California State University, Los Angeles (1981)

80. YAMATO, M. \& K. HASHIGAKI: Chemical structure and sweet taste of isocoumarins and related compounds. Chem. Senses and Flavour 4, 35 (1979). S.a., M. Yamato, K. Hashigaki, K. Mito \& T. Koyama. Chem. Pharm. Bull. 26, 2321 (1978) 